${ }^{3}$ Crichton RR. Interactions between iron metabolism and oxygen activation. In: Oxygen free radicals and tissue damage. Amsterdam: Excerpta Medica, 1979. (Ciba Foundation Symposium 65.)

${ }^{4}$ Williams BD, Pussell BA, Lockwood CM, Cotton C. Defective reticuloendothelial system function in rheumatoid arthritis. Lancet 1979;i: 1311-4.

${ }^{5}$ Lloyd KN, Williams P. Reactions to total dose infusion of iron dextran in rheumatoid arthritis. $\mathrm{Br} \mathrm{Med} \mathcal{F} 1970$;ii:323-5.

(Accepted 12 February 1981)

Royal National Hospital for Rheumatic Diseases, Bath BA1 1RL

D R BLAKE, MRCP, senior registrar

P A BACON, FRCP, consultant rheumatologist

\section{High-density lipoprotein and other risk factors for coronary artery disease assessed by angiography}

Total blood cholesterol and low-density lipoprotein cholesterol concentrations are well-established risk factors for the development of coronary artery disease, ${ }^{1}$ whereas high-density lipoprotein cholesterol constitutes a negative risk factor for coronary disease $\mathrm{e}^{2}$ - that is, may exert a protective effect. The Framingham study ${ }^{1}$ showed that the ratio of high-density lipoprotein cholesterol to total cholesterol may be an even more powerful negative risk factor. As neither the presence nor severity of coronary artery disease can be determined accurately by clinical or electrocardiographic examination, our study compared the serum total cholesterol and total high-density lipoprotein cholesterol concentrations and the ratio of high-density lipoprotein cholesterol to total cholesterol with the degree of coronary artery disease assessed angiographically.

\section{Patients, method, and results}

We studied 160 consecutive patients undergoing coronary angiography for the investigation of chest pain or assessment of valvular heart disease. The angiograms were reported independently by a consultant radiologist. Lesions were graded visually from 0 to $4: 0=$ normal, $1=25 \%$ stenosis, $2=50 \%$ stenosis, $3=75 \%$ stenosis, and $4=$ total occlusion.

A coronary index was calculated using the method designed by Balcon et $a l^{3}$ which takes into account the site, severity, and effect of multiple lesions in the coronary circulation. The index ranges from 0 to 1 , where $0=$ total occlusion of all vessels and $1=$ normal coronary circulation. Twenty-four hours before catheterisation the serum total cholesterol and high-density lipoprotein cholesterol concentrations were measured after a 12-hour fast. Cholesterol and triglyceride concentrations were measured by semiautomated fluorometric techniques, Technicon method N77 and LiebermannBurchard's reagent being used for cholesterol and Cramp and Robertson's method for triglyceride. High-density lipoprotein cholesterol was measured as for plasma cholesterol after precipitation with heparin (250 units in $50 \mu \mathrm{l}$ ) and manganese chloride ( $50 \mu \mathrm{l} 1 \mathrm{M}$ solution).
The 160 patients were divided into quartiles on the basis of mean serum cholesterol and high-density lipoprotein cholesterol concentrations and the ratio of high-density lipoprotein cholesterol to total cholesterol. The coronary indices of the patients in the top and bottom quartiles for the respective lipid profiles were determined for comparison. Also, patients with normal coronary arteries were compared with an equivalent number of patients with the severest coronary artery disease for differences in lipoprotein concentrations. Other risk factors such as age, the number of cigarettes smoked daily, and systolic and diastolic blood pressures were also considered. The MannWhitney $U$ non-parametric test was applied in all statistical analyses.

The table gives clinical details of the patients and the coronary indices, and shows significant differences between the groups.

\section{Comment}

Jenkins et $a l, 4$ in a study similar to ours, showed a significant inverse relation between high-density lipoprotein concentrations and the severity of coronary artery disease assessed angiographically, This association was not found in the present study $(p<0 \cdot 11)$. Total cholesterol, however, was significantly associated with severity of coronary artery disease, and the ratio of high-density lipoprotein cholesterol to total cholesterol was inversely related to the severity of coronary disease. Of these two variables, the inverse relation of the ratio was slightly stronger ( $p<0.001$ and $p=0.01$ respectively).

Apart from a significant age difference between the two quartiles with high and low concentrations of high-density lipoprotein cholesterol $(p=0.05)$, there were no significant differences in age, number of cigarettes smoked daily; and systolic and diastolic blood pressures between the upper and lower quartiles. When the data were analysed by comparing patients with the severest coronary occlusion (coronary index $<0.42$ ) with those with no occlusion, however, those with the severest occlusion were found to be older $(p=0.04)$ and heavier smokers and to have higher blood pressure $(p=0.02)$, as well as having a lower ratio of high-density lipoprotein to total cholesterol $(p<0.01)$.

These results support the suggestion of Williams et $\mathrm{al}^{5}$ that the ratio of high-density lipoprotein cholesterol to total cholesterol should be included in any coronary risk screening profile.

1 Gordon T, Castelli WP, Hiortland ME, Kannel WB, Dawber TR. High density lipoprotein as a protective factor against coronary heart disease. Am $\mathcal{F}$ Med 1977;62:707-14.

${ }^{2}$ Reckless JPD, Betteridge DJ, Wu P, Payne B, Galton DJ. High density and low density lipoproteins and prevalence of vascular disease in diabetes mellitus. $\mathrm{Br}$ Med 7 1978; :883-6.

${ }^{3}$ Balcon R, Cattell MR, Stone DL, Fuerlicht JA. A computer generated index for the assessment of coronary angiography. Acta Med Scand 1978; 615, suppl: $25-30$.

4 Jenkins PJ, Harper RW, Nestel PJ. Severity of coronary atherosclerosis related to lipoprotein concentration. $B r$ Med 7 1978;ii:388-91.

${ }^{5}$ Williams P, Robinson D, Bailey A. High density lipoprotein and coronary risk factors in man. Lancet $1979 ; \mathrm{i}: 72-5$.

(Accepted 12 February 1981)

St Bartholomew's Hospital, London EC1

J R MILNE, MRCP, senior registrar in general medicine and cardiology

D L STONE, MRCP, senior registrar in cardiology

S O BANIM, MRCP, consultant cardiologist

D J GALTON, MD, FRCP, consultant physician

R S O REES, FRCR, FRCP, consultant radiologist

Clinical details, lipid measurements, and coronary indices (expressed as means $+S D$ ) of patient groups analysed by quartiles

\begin{tabular}{|c|c|c|c|c|c|c|c|c|c|c|c|}
\hline \multirow{2}{*}{ Patient group } & \multicolumn{2}{|c|}{ Sex } & \multirow{2}{*}{ Age (years) } & \multicolumn{2}{|c|}{ Blood pressure (mm $\mathrm{Hg})$} & \multirow{2}{*}{$\begin{array}{c}\text { No of } \\
\text { smokers }\end{array}$} & \multirow{2}{*}{$\begin{array}{l}\text { Mean No } \\
\text { of cigarettes } \\
\text { smoked daily }\end{array}$} & \multirow{2}{*}{$\begin{array}{l}\text { Plasma } \\
\text { cholesterol } \\
(\mathrm{mmol} / 1)\end{array}$} & \multirow{2}{*}{$\begin{array}{c}\text { Plasma } \\
\text { high-density } \\
\text { lipoprotein } \\
\text { cholesterol } \\
(\mathrm{mmol} / \mathrm{l})\end{array}$} & \multirow{2}{*}{$\begin{array}{l}\text { High-density } \\
\text { lipoprotein } \\
\text { cholesterol: } \\
\text { total } \\
\text { cholesterol }\end{array}$} & \multirow{2}{*}{$\begin{array}{l}\text { Coronary } \\
\text { index }\end{array}$} \\
\hline & $\mathbf{M}$ & $\mathrm{F}$ & & Systolic & Diastolic & & & & & & \\
\hline $\begin{array}{l}\text { Cholesterol: } \\
\text { Upper quartile } \\
\text { Lower quartile } \\
\text { High-density lipoprotein }\end{array}$ & $\begin{array}{l}33 \\
27\end{array}$ & $\begin{array}{r}7 \\
13\end{array}$ & $\begin{array}{l}54 \cdot 4 \pm 8 \cdot 8 \\
54 \cdot 9 \pm 8 \cdot 4\end{array}$ & $\begin{array}{l}144 \pm 23 \\
144 \pm 22\end{array}$ & $\begin{array}{l}89 \pm 12 \\
85 \pm 12\end{array}$ & $\begin{array}{l}16 \\
18\end{array}$ & $\begin{array}{l}22 \cdot 9 \\
20 \cdot 0\end{array}$ & $\begin{array}{l}8 \cdot 0 \pm 0 \cdot 88 \\
4 \cdot 8 \pm 0.51\end{array}$ & & & $\begin{array}{l}0.5 \pm 0.31 \\
0.71 \pm 0.32 \ddagger\end{array}$ \\
\hline $\begin{array}{l}\text { cholesterol: } \\
\text { Upper quartile } \\
\text { Lower quartile } \\
\text { High-density lipoprotein } \\
\text { cholesterol : total } \\
\text { cholesterol: }\end{array}$ & $\begin{array}{l}23 \\
34\end{array}$ & $\begin{array}{r}17 \\
6\end{array}$ & $\begin{array}{l}57 \cdot 4 \pm 8 \cdot 4 \\
53 \cdot 4 \pm 7 \cdot 7^{*}\end{array}$ & $\begin{array}{l}141 \pm 22 \\
136 \pm 23\end{array}$ & $\begin{array}{l}85 \pm 12 \\
85 \pm 12\end{array}$ & $\begin{array}{l}15 \\
20\end{array}$ & $\begin{array}{l}15 \cdot 6 \\
26 \cdot 9\end{array}$ & & $\begin{array}{l}1.4 \pm 0.51 \\
0.67 \pm 0.09\end{array}$ & & $\begin{array}{l}0.71 \pm 0.33 \\
0.58 \pm 0.32\end{array}$ \\
\hline $\begin{array}{l}\text { Upper quartile } \\
\text { Lower quartile } \\
\text { Patients with coronary } \\
\text { index of: }\end{array}$ & $\begin{array}{l}26 \\
36\end{array}$ & $\begin{array}{r}14 \\
4\end{array}$ & $\begin{array}{l}55 \cdot 7 \pm 8 \cdot 6 \\
52 \cdot 9 \pm 8 \cdot 8\end{array}$ & $\begin{array}{l}141 \pm 23 \\
140 \pm 24\end{array}$ & $\begin{array}{l}85 \pm 14 \\
86 \pm 13\end{array}$ & $\begin{array}{l}15 \\
23\end{array}$ & $\begin{array}{l}18 \cdot 5 \\
22 \cdot 1\end{array}$ & & & $\begin{array}{l}0.24 \pm 0.04 \\
0.1 \pm 0.01\end{array}$ & $\begin{array}{l}0.78 \pm 0.34 \\
0.52 \pm 0.28 \S\end{array}$ \\
\hline $\begin{array}{l}1<0.42 \\
<0 .\end{array}$ & $\begin{array}{l}33 \\
49\end{array}$ & $\begin{array}{r}23 \\
7\end{array}$ & $\begin{array}{l}52 \cdot 9 \pm 9 \cdot 9 \\
56 \cdot 1 \pm 6 \cdot 3^{*}\end{array}$ & $\begin{array}{l}136 \pm 22 \\
145 \pm 25 \dagger\end{array}$ & $\begin{array}{l}85 \pm 13 \\
89 \pm 13\end{array}$ & $\begin{array}{l}27 \\
36\end{array}$ & $\begin{array}{l}18 \cdot 0 \\
26 \cdot 0\end{array}$ & $\begin{array}{l}5 \cdot 9 \pm 1 \cdot 2 \\
6 \cdot 7 \pm 1 \cdot 6 \pm\end{array}$ & $\begin{array}{l}1 \cdot 05+0.28 \\
1 \cdot 0+0 \cdot 29\end{array}$ & $\begin{array}{l}0.18 \pm 0.06 \\
0.15 \pm 0.05_{+}^{+}\end{array}$ & $\begin{array}{l}1 \cdot 0 \\
0 \cdot 25 \pm 0 \cdot 1\end{array}$ \\
\hline
\end{tabular}

Significance of differences (Mann-Whitney U test): ${ }^{*} p=0.04 ; \dagger p=0.02 ; \ddagger p<0.01 ; \S p<0.001$

Significance of differences (Mann-Whitney $U$ test $):{ }^{*} \mathrm{p}=0.04 ;+\mathrm{p}=0.02 ;+$
Conversion: SI to traditional units-Cholesterol: $1 \mathrm{mmol} / 1 \approx 38 \cdot 7 \mathrm{mg} / 100 \mathrm{ml}$. 